\title{
EVALUATION OF RELIABILITY OF RADIO-ELECTRONIC DEVICES WITH VARIABLE STRUCTURE
}

Ryzhov Ye. V. - PhD, Head of the Research Laboratory of the Informational and Geoinformational Technologies at the Scientific Center of the Hetman Petro Sahaidachnyi National Army Academy, Lviv, Ukraine.

Sakovich L. N. - PhD, Associate Professor, Assistant Professor of Special Department of the Institute of Special Communication and Information Protection of KPI named after Igor Sikorsky, Kyiv, Ukraine.

Puchkov O. O. -PhD, Professor, Head of the Institute of Special Communication and Information Protection of KPI named after Igor Sikorsky, Kyiv, Ukraine.

Nebesna Ya. E. - Head of the Planning and Controlling Sector of the Educational Department of the Institute of Special Communication and Information Protection of KPI named after Igor Sikorsky, Kyiv, Ukraine.

\section{ABSTRACT}

Context. Various radio electronic devices are being continuously developed and refined in order to improve the quality indicators according to the consumers' requirements for their use in multiple operational modes, each with separate subsets of elements. Given fact is not taken into account when assessing the reliability indicators, which leads to a decrease in their value, and, as a consequence, to an increase in the products cost.

Objective. The purpose of the article is to improve the quantification accuracy of reliability values of electronic devices with variable structure by using a new model, which takes into account the operational time of individual subsets of elements of the object in its possible operational modes.

Method. The paper analyzes the structures of radio electronic devices and their influence on reliability using methods of set theory, probability theory, discrete search theory and metrology. This allows objective quantification of reliability indicators values depending on the conditions of the product use: operating time for failure, average recovery time and the readiness coefficient.

Results. An improved model of reliability of multiple mode objects with variable structure, which takes into account the features of structural design of the product, the features of its intended use (operating time in separate modes), and the influence of the quality of metrological support on the average recovery time has been obtained. This allows increasing the estimation of the real value of the complex indicator of reliability - readiness coefficient, and, as a consequence, reducing the value of the readiness coefficient.

Conclusions. The use of the proposed model of quantitative estimation of the reliability indicators' values of radio electronic devices with variable structure can reduce the cost of products while providing the required values of failure time and the average recovery time by reducing the requirements for the reliability of the base elements. The results obtained should be used in the design of perspective radio electronic devices to justify the choice of element of the minimum cost base while meeting the required requirements for the reliability of the product as a whole.

KEYWORDS: radio-electronic devices with variable structure, rating of reliability indicators, mean time between failures, average recovery time.

\section{ABBREVIATIONS \\ $\mathrm{RED}$ is a radio-electronic devices; \\ MTBF is a mean time between failures.}

\section{NOMENCLATURE}

$Z_{i}$ is a parameter failure flow of individual elements;

$T_{p i}$ is a operating time of the product in individual modes;

$u_{i}$ is a value of the relative coefficient of each element usage;

$T_{p}$ is a total time of the product operation in all possible modes;

$N$ is a quantify rate the number of each element failures;

$T_{p i} / T_{p}=N_{i}$ is the MTBF for the separate subsets of elements

$T$ is the MTBF for the RED as a whole;

$n$ is a quantity of subsets of RED elements, which are used in various modes;

$Z$ is a parameter failure flux parameter.

$T_{\text {art }}$ is an average recovery time RED; $t$ is an average time for performing the parameter check;

$t_{m r}$ is an average time for malfunction repair;

$K_{i}$ is an average checks quantity to find defects in a subset of elements $L_{i}$;

$L$ is a total RED elements;

$T_{\text {etr }}$ is an estimated time of recovery of the RED;

$A$ is a complex product reliability indicator readiness coefficient;

$U=1-A$ is an unreadiness coefficient;

$P$ is a probability of correct diagnosis;

$p$ is a probability of correct estimation of the result of the RED performance parameter check;

$P(\tau)$ is a metrological reliability of the measuring instruments;

$\tau$ is a period of measuring instruments verification;

$T_{\text {perm. }}$ is a permissible values for the operation time for failure;

$T_{\text {art. perm. }}$ is a permissible average recovery time;

$x$ is a parameters, which affect the product reliability; 
$x^{*}$ is a value of parameters $x$ in the problem solving; limits.

$\Delta$ is an area of allowable parameters values change

$U^{\prime}$ is a relative reduction in the unreadiness coefficient;

$M_{1}$ is a set of elements used in the "transmission mode";

$M_{2}$ is a set of elements used in the "receive" mode;

$M_{12}$ is a kernel used in both operation modes.

\section{INTRODUCTION}

RED of various purposes are instantly developing and improving the quality indicators according to the requirements of consumers, by introduction of new diagram and constitutive solutions, as well as the use of modern elements of the base. This causes a corresponding complication of products, which does not lead to an improvement in the values of their reliability indicators. Therefore, the issue of providing the required level of modern RED reliability is very important for both manufacturers and consumers.

Extension of the capabilities of REM is achieved by their multi-mode regime, such that different sets of elements are used to satisfy individual consumer requirements. However, such an approach implies that the structure of the object changes in the course of its exploitation. This direction in the theory of technical reliability has not been explored enough yet, which results in the underestimation of the values of the time between failures of products, and this, in its turn, requires the use of a more reliable and thereby a more expensive element base.

The object of study is the reliability of technical objects with variable structure, and the subject of the study is the process of quantifying the values of the reliability of many mode objects.

The purpose of the article is to increase the accuracy of the quantitative assessment of the reliability of radio electronic devices with a variable structure through the use of a new model that takes into account the operation time of individual elements of the object in different operation modes and increases the calculations accuracy, taking into account the construction features and intended use of these objects.

\section{PROBLEM STATEMENT}

To increase the accuracy of the quantitative assessment of the reliability indicators of the objects with a variable structure, one has to develop a mathematical model, which will take into account the properties of multi-mode regime (the use of various subsets of elements depending on the operational mode), as well as the time of the functioning of the object in each mode. In addition, when quantifying the average recovery time, it is necessary to take into account the quality of metrological support (metrological reliability of measuring instruments). For a quantitative description of the variable structure of an object, it is advisable to use the (C) Ryzhov Ye. V., Sakovich L. N., Puchkov O. O. Nebesna Ya. E., 2020 DOI 10.15588/1607-3274-2020-3-3 mathematical apparatus of the set theory with the introduction of the coefficient of exploitation for each subset of elements during operation. This will allow one to evaluate the parameter of the flow of failures, for each individual operating mode as well as for the product as a whole, which are needed for further calculation of the mean time between failures. The accuracy of the quantitative assessment of the average recovery time can be improved by taking into account the failure probabilities of subsets of elements and the characteristic parameters of diagnostic algorithms. The order of localization of faults is estimated by the average number of inspections needed to find faulty elements in a subset. This will allow one to assess the probability of a correct diagnosis. To our best knowledge, the directions mentioned above have not been yet comprehensively considered in the literature.

Their implementation is aimed to minimize the value of an integral indicator of reliability, i.e. the coefficient of unavailability. The problem is solved by the variation of the controlled variables in the range of permissible values.

Thus, the target studies function is to minimize the value of the complex product reliability indicator - the unreadiness coefficient with restrictions on the allowable values for the operation time for failure $\left(T_{\text {perm. }}\right)$ and the average recovery time $\left(T_{\text {art.perm. }}\right)$, determined by the guidance documents, at a given operating mode $\left(T_{p i}, u_{i}\right)$, is presented like the following:

$$
\begin{gathered}
U(x)=\min U\left(x^{*}\right) ; x^{*} \in \Delta ; \\
x=\left(L_{i}, u_{i}, T_{p i}, Z_{i}, n, p, t, t_{m r}, r(\tau), T, T_{\text {art. }}\right) ; \\
T=\left(T_{p i}, u_{i}, Z_{i}, n\right) \geq T_{\text {perm. }} ; \\
T_{\text {art. }}\left(t, t_{m r}, K, p, P(\tau)\right) \leq T_{\text {art.perm. }} .
\end{gathered}
$$

Unmanageable parameters groups:

$L_{i}, n, Z_{i}$ - depend on the product scheme and the reliability of the element base.

Parameters groups, manageable during the product usage:

$T_{i}, u_{i}$ - depends on product operating mode;

$t, t_{m r}$ - depends on operators qualification and work efficiency restoration conditions;

$K$ - depends on the quality of diagnostic support and the form of conditional algorithms for defects searching;

$p, P(\tau)-$ depend on the measuring equipment used during the current maintenance to estimate the values of the signals at the control points of the product.

In this case, as an indicator of efficiency, it is appropriate to use a relative reduction in the unreadiness coefficient, whose value is calculated using known techniques $\left(U^{\prime}\right)$, in comparison with the suggested model of reliability of variable structure objects $(U)$

$$
\eta=100 \cdot\left(U^{\prime}-U\right) / U \% \text {. }
$$


To solve this problem, it is necessary to develop a mathematical model for estimating the values of reliability indicators of RED with variable structure, which is presented in this article.

\section{REVIEW OF THE LITERATURE}

Known methods for providing the required values of REDs reliability indicators by reserving the least reliable structural units, increase their cost and mass-grossing indicators, as well as the amount of spare parts, instruments and accessories for realizing the maintenance by the aggregate method [1, 2]. The directions of automatization of RED reliability indicators calculations and their changes with time [3] are also researched.

The promising direction of RED development in the communications area is the implementation of softwarecontrolled devices, counting that the quality of devices software also affects the reliability of individual products and communications systems in general [4].

Not only the MTBF, but also the average time of recovery [5] substantially affects the value of a complex REDs reliability indicator - their readiness coefficient, therefore, in the special technical literature [6, 7], research and dissertation papers pay attention to the elevation of quality of the diagnostic maintenance provided. However, during the quantitative assessment of the values of RED reliability indicators, which are determined by the design tasks, the properties of multi-mode are not taken into account, which leads to a change in the structure of objects during their intended use.

Nowadays, the engineering methods and theoretical developments of the analysis of the technical systems with variable structure reliability, which is due to its multi-functionality and multi-mode, when the corresponding sets of elements are used in certain operation modes [2], are not presented. Multi-mode properties are used in the development of diagnostic support [6, 7], but when reliability is rated, it is traditionally believed that all elements of the object work simultaneously $[5,8]$, which significantly reduces the value of the operation time for failure.

Currently, modern domestic and foreign publications on the topical issues of complex technical objects and systems reliability consider separate directions of increasing the values of their reliability indicators [9-14]. However, these publications do not consider the issues complex account of the individual components reliability of programmed-controlled multi-mode communications devices with a variable structure during the evaluation of their indicators both in the design process and in specification during the experimental operation.

\section{MATERIALS AND METHODS}

The task of development upgradable and perspective samples of multi-mode RED is to normalize the value of the operation time for failure and the average time for the repair of existing ones. Therefore, during design, it is necessary to perform a reliability calculation with a quantification of all reliability indicators, which are then checked during experimental operation.

The communications devices relate to a class of objects with a variable structure, which can be uni- and multifunctional, multi-mode with a fixed or random change of operation modes. For example, the radio station is in "reception" or "transmission" mode, while the order of operation modes changes is not fixed. The system of the operations control of a high power radio transmitter successively, in a fixed order changes the number of elements as it turns on (input, cooling, heating, biasing, high voltage).

To simulate these objects, the well-known mathematical apparatus of the theory of sets $[1,7]$ is used but only during the development of diagnostic support. Multiple-theoretical models allow us to rate the power of sets of elements used in individual operation modes, as well as their interconnections. For example, when a fixed change of modes it is appropriate to use a "garland" model, when with each step the number of involved elements of the object increases. This leads to a decrease in the operation time for failure and an increase in the average recovery time, which impair the value of the complex reliability indicator - the readiness coefficient of the object.

When using a random change of the modes of the radio receiver or radio station, it is appropriate to use the multiple-theoretical model with intersections of elements subsets, which have a kernel (for example, amplifiers, power supply or generator equipment). In this case, the reliability of individual subsets of the elements is significantly influenced by their operation time in the given mode (for example, the time of the radio station in the "receiving" mode is few times greater than "transmission"), i.e. the technical resource of the elements varies unevenly.

In order to take into account this circumstance, it is suggested to apply a coefficient of the intended use of each subset of elements in the possible operation modes of the product, which is calculated as the ratio of the working time of the subset of the elements to the total operating time of the product in all possible modes. Its value can be rated quantitatively from the analysis of the communications devices usage, as reflected in the hardware logs of the communications centers.

Let us consider the order of using these suggestions with an example of a multi-mode object, the scheme of which is shown in Fig. 1. The object works in three modes, each of which uses five of the eight common subset of elements. This is a multiple-theoretical model with strong intersections of a subset of elements and a kernel, consisting of elements 7 and 8 , which are used in all operation modes. 

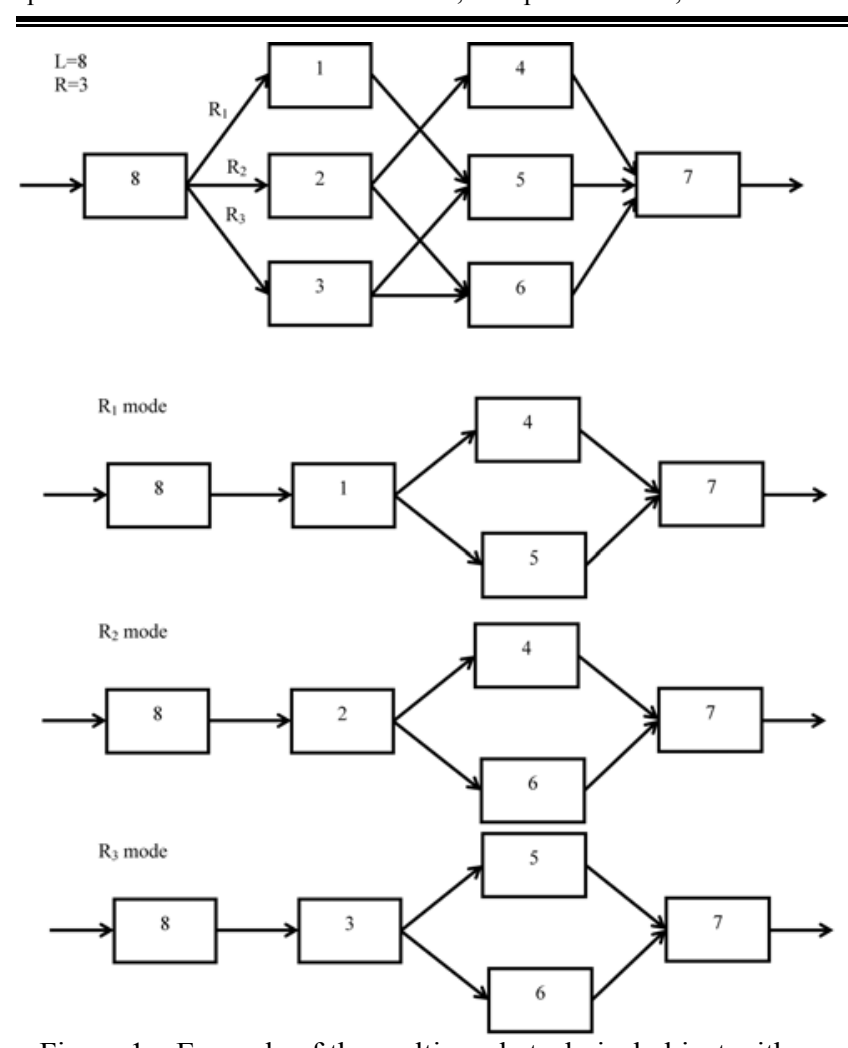

Figure 1 - Example of the multi-mode technical object with a

kernel and powerful intersection of the subset of elements

In the traditional indicative calculation of reliability, the minimum and maximum values of the parameter failure flow of individual elements $\left(Z_{i}\right)$ are being added, and then the boundaries of change and the average value of the operation time for failure are determined $[3,5,8]$.

$$
T=1 / \sum_{i=1}^{L} Z_{i}
$$

In this case, the real work time of individual elements is not accounted.

If the value of the parameter $Z_{R i}$ of the individual product elements failure, then for each mode we get:

$$
\begin{aligned}
& Z_{R_{1}}=Z_{1}+Z_{4}+Z_{5}+Z_{7}+Z_{8} \\
& Z_{R_{2}}=Z_{2}+Z_{4}+Z_{6}+Z_{7}+Z_{8} \\
& Z_{R_{3}}=Z_{3}+Z_{5}+Z_{6}+Z_{7}+Z_{8} .
\end{aligned}
$$

In that case, the operation time for failure of the product in every mode is equal to:

$$
T_{1}=\frac{1}{Z_{R_{1}}} ; \quad T_{2}=\frac{1}{Z_{R_{2}}} ; \quad T_{3}=\frac{1}{Z_{R_{3}}} .
$$

If there exists an extra data on the operating time of the product in individual modes $\left(T_{p i}\right)$, it is possible to calculate the value of the relative coefficient of each element usage $\left(u_{i}\right)$, respectively:

$$
u_{1}=\frac{T_{p 1}}{T_{p}} ; \quad u_{2}=\frac{T_{p 2}}{T_{p}} ; \quad u_{3}=\frac{T_{p 3}}{T_{p}} ;
$$

(C) Ryzhov Ye. V., Sakovich L. N., Puchkov O. O. Nebesna Ya. E., 2020 DOI 10.15588/1607-3274-2020-3-3

$$
\begin{gathered}
u_{4}=\frac{T_{p 1}+T_{p 2}}{T_{p}} ; u_{5}=\frac{T_{p 1}+T_{p 3}}{T_{p}} ; u_{6}=\frac{T_{p 2}+T_{p 3}}{T_{p}} \\
u_{7}=1 ; u_{8}=1 ; T_{p}=T_{p 1}+T_{p 2}+T_{p 3} .
\end{gathered}
$$

This allows accounting the specific MTBF for each element, to quantify rate the number of their failures $(N)$ and the product as a whole:

$$
N=T_{p} \sum_{i=1}^{8} U_{i} Z_{i}=\sum_{i=1}^{8} Z_{i} T_{p i}=\sum_{i=1}^{8} \frac{T_{p i}}{T_{i}} .
$$

Then, the failure flux parameter of the product equals:

$$
Z=\frac{N}{T_{p}}=\sum_{i=1}^{8} U_{i} Z_{i}
$$

The MTBF accounting for the operation time of elements subsets in separate modes, respectively

$$
T=T_{p} / N \text {. }
$$

Suppose that all subsets of the elements in the example considered are equally reliable $\left(Z_{i}=Z\right)$, and in each mode the product runs at the same time $\left(T_{p i}=T_{p} / 3\right)$, then we obtain:

$$
u_{1}=u_{2}=u_{3}=1 / 3 ; \quad u_{4}=u_{5}=u_{6}=2 / 3 ; \quad u_{7}=u_{8}=1 .
$$

Total failure count of the product for 1 working hour $T_{p}$ is:

$$
N=Z \cdot T_{p} \sum_{i=1}^{8} u_{i}=5 Z \cdot T_{p},
$$

and MTBF is $T=1 / 5 Z$.

Under the same conditions, with a traditional indicative calculation of reliability, get $T^{\prime}=1 / 8 Z$, that is, the real value of the product's failure, accounting its property of multi-mode, has increased in $T / T^{\prime}=1.6$ times, or by $\left[\left(T-T^{\prime} / T^{\prime}\right)\right] \cdot 100 \%=37.5 \%$.

Obviously, the greater the number of possible operation modes of the product is, the more accurate the rate of the value of the work time failure, accounting the properties of multi-modes, is. However, it requires additional output data for the estimated operation time of the product in each mode. Currently, when designing new or updating existing RED and special communications devices, an indicative and specified calculation of reliability indicators is performed [1,2].

In the first case, all elements of the product are divided into groups (resistors, capacitors, transistors, diodes, microcircuits, etc.) with approximately the same value of the failure rate; both the minimum and the maximum values obtained from the reference books are considered. Then we multiply the number of elements of each group to the limit values of the failures intensity and sum the results. In this way, the limit values of the product failure flow parameter are calculated and the 
value of the operation time for failure value is calculated. If the required value stays in these limits, then a specified calculation of reliability is performed. If not, you need to change the elements for more reliable and repeat the calculation.

When the specified reliability is calculated, the average values of the failure rate of each element takes into account the coefficient of its electric load, as well as the climatic conditions (temperature, humidity, pressure) and mechanical load (vibration, impact) depending on the conditions of further products operation. In both cases, the operation time of the elements in separate modes $\left(T_{p}\right)$ is not accounted, which understated the real value of the operation time for failure [1-5] of the RED in general.

The MTBF ( $T$ ) for the RED as a whole depends on this indicator for individual parts of the product, which are used in various operating modes $\left(T_{i}\right)$, which, in turn, is determined by the failure parameter of this subset of elements $\left(Z_{i}\right)$

$$
T_{i}=1 / Z_{i}
$$

The property of many RED modes is accounted by introducing the coefficient of individual sets of elements usage depending on the relative time of their work $\left(T_{p i}\right)$

$$
u_{i}=T_{p i} / T_{p} ; \quad i=\overline{1, n} .
$$

In that case, the total failure count of product per hour $T_{p}$ is

$$
N=\sum_{i=1}^{n} \frac{T_{p i}}{T_{i}}=T_{p} \sum_{i=1}^{n} u_{i} Z_{i}
$$

and RED failure flux parameter in total equals

$$
T=\frac{T_{p}}{N}=1 / \sum_{i=1} u_{i} Z_{i}=\frac{1}{Z} .
$$

Another reliability indicator of a RED, that is normalized and specified by the guidance documents, is the average recovery time $T_{\text {art }}$ It depends on the qualification of the performers $(t$ is the average time for performing the parameter check, $t_{m r}$ is the average time for malfunction repair), the quality of the metrological and diagnostic support [6-8], the power of the subsets of the elements used in the individual operating modes of the product, and the probability of their failure.

When looking for defects during the current maintenance of the programs, based on the use of conditional algorithms of the minimum form, the average checks quantity $[6,7]$ is

$$
K_{i}=\log _{2} L_{i} ; \quad i=\overline{1, n} .
$$

An average checks quantity during the current maintenance of the product, in total is

$$
K=\frac{1}{n} \sum_{i=1}^{n} \log _{2} L_{i}
$$

here with, total RED elements quantity

$$
L=\sum_{i=1}^{n} L_{i}
$$

provided that subset elements are used only in separate work modes, where average checks quantity is $K=\frac{1}{n} \sum_{i=1}^{n} \log _{2} L_{i}$.

The probability of product failure due to defect appears among the elements $L_{i}$ equals

$$
\frac{N_{i}}{N}=\frac{T_{p i}}{T_{i} T_{p} \sum_{i=1}^{n} u_{i} Z_{i}}=\frac{u_{i} T_{p}}{\frac{1}{Z_{i}} T_{p} Z}=\frac{u_{i} Z_{i}}{Z},
$$

here with

$$
T \sum_{i=1}^{n} Z_{i} u_{i}=1
$$

The average recovery time of a product is a discrete random variable, whose mathematical expectation is the sum of the multiplication of their possible values $\left(K_{i}\right)$ for the probability of their occurrence $\left(u_{i} Z i / Z\right)$ [15]. Then, the estimated time of recovery of the RED (without accounting the metrological reliability of the measuring instruments) equals

$$
T_{e t r}=t_{m r}+\frac{t}{Z} \sum_{i=1}^{n} u_{i} Z_{i} \log _{2} L_{i}
$$

In that case, the complex product reliability indicatorreadiness coefficient, equals

$$
A=\frac{T}{T+T_{a t r}}=1 /\left[1+t \sum_{i=1}^{n} u_{i} Z_{i} \log _{2} L_{i}+t_{m r} \sum_{i=1}^{n} u_{i} Z_{i}\right] .
$$

This expression does not account the probability of correct diagnosis [16]

$$
P=p^{K} .
$$

The obtained results are summarized in table.1, which stands as mathematical model for rating the values of reliability indicators of radio-electronic devices with variable structure.

The suggested model differs from the known ones, by accounting the work time of product in individual operation modes, the failure probability in each operation mode and metrological reliability of the measuring equipment. 
e-ISSN 1607-3274 Радіоелектроніка, інформатика, управління. 2020. № 3 p-ISSN 2313-688X Radio Electronics, Computer Science, Control. 2020. № 3

Table 1 - Mathematical model for rating the values of reliability indicators of radio electronic devices with variable structure

\begin{tabular}{|c|c|c|}
\hline \multirow{2}{*}{ Indicator } & \multicolumn{2}{|c|}{ Functional Dependences } \\
\hline & Without accounting multi-mode operations & Accounting multi-mode operations \\
\hline Failure flux parameter & $Z^{\prime}=\sum_{i=1}^{n} Z_{i}$ & $Z^{\prime}=\sum_{i=1}^{n} u_{i} Z_{i}$ \\
\hline MTBF & $T^{\prime}=1 / Z^{\prime}$ & $T=1 / Z$ \\
\hline $\begin{array}{l}\text { Total failure count } \\
\text { per hour } T_{p}\end{array}$ & $N^{\prime}=T_{p} \sum_{i=1}^{n} Z_{i}$ & $N=T_{p} \sum_{i=1}^{n} u_{i} Z_{i}$ \\
\hline Estimated average recovery time & $T_{e t r}^{\prime}=t_{m r}+\frac{t}{n} \sum_{i=1}^{n} \log _{2} L_{i}$ & $T_{e t r}=t_{m r}+\frac{t}{n} \sum_{i=1}^{n} u_{i} Z_{i} \log _{2} L_{i}$ \\
\hline Quantity of average checks & \multicolumn{2}{|c|}{$K=\frac{1}{n} \sum_{i=1}^{n} \log _{2} L_{i}$} \\
\hline Probability of correct diagnosis & \multicolumn{2}{|c|}{$P=p^{K}$} \\
\hline Average recovery time & $T_{\text {art }}^{\prime}=\frac{T_{\text {etr }}^{\prime}}{P}$ & $T_{\text {art }}=\frac{T_{e t r}}{P \cdot P(\tau)}$ \\
\hline Product readiness coefficient & $A^{\prime}=\frac{T^{\prime}}{T^{\prime}+T_{\text {art }}^{\prime}}$ & $A=\frac{T}{T+T_{\text {art }}}$ \\
\hline Product unreadiness coefficient & $U^{\prime}=\frac{T_{\text {art }}^{\prime}}{T^{\prime}+T_{\text {art }}^{\prime}}$ & $U=\frac{T_{\text {art }}}{T+T_{\text {art }}}$ \\
\hline Model using effect & \multicolumn{2}{|c|}{$\eta=\frac{U^{\prime}-U}{U^{\prime}} 100 \%$} \\
\hline
\end{tabular}

The adequacy of the model is confirmed by the fact that the formulas, obtained in the right column of the table. 1 for $u_{i}=1$ and $P(\tau)=1$ without accounting the failure probability of subsets of elements $L_{i}$, are converted into expressions, which are given in the left column of table 1 .

\section{EXPERIMENTS}

Let us consider the order of using the obtained results in the example of rating the values of reliability indicators of the new generation radio station [17]. Multipletheoretical model of the radio station is shown in Fig. 2, where $M_{1}$ - the set of elements used in the "transmission mode", $M_{2}$ - in the "receive" mode, $M_{12}$ - the kernel used in both operation modes (power supply subsystems, control and operation, generator equipment, antenna).

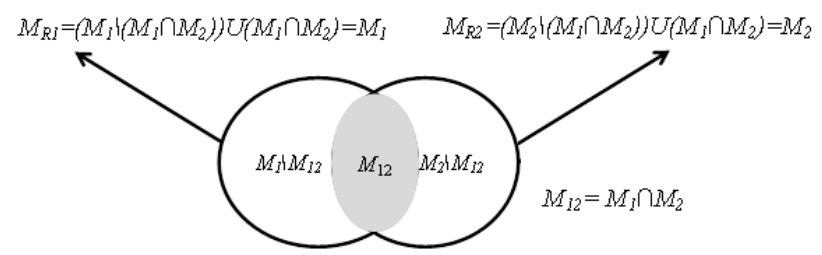

Figure 2 - Multiple-theoretical radio station model of the tactical control unit

The total number of radio station elements is $L=4096$, of which both modes use the total number of
$L_{3}=512$ elements, in the "receive" mode $L_{2}=3072$ elements and in the "transfer" mode $L_{1}=1024$ elements. At the same time $Z_{1}=307 \cdot 10^{-6} \mathrm{hrs}^{-1}$, $Z_{2}=532 \cdot 10^{-6} \mathrm{hrs}^{-2}, Z_{3}=154 \cdot 10^{-6} \mathrm{hrs}^{-1}$.

Excluding multi-mode properties, we have $(n=3)$

$$
Z^{\prime}=\sum_{i=1}^{3} Z_{i}=993 \cdot 10^{-6} h r s^{-1},
$$

the MTBF is $T^{\prime}=1007 \mathrm{hrs}$. during the current maintenance of radio stations using measuring equipment with metrological characteristics $p=0,997$ and $P(\tau)=0,96$ [16]. If the conditional diagnostic algorithms are used during the current maintenance, then $K=8,86$. Assuming that the qualification of specialists provides $t=3,5 \mathrm{~min}$ and $t_{m r}=8 \mathrm{~min}$, we obtain the average recovery time $T^{\prime}{ }_{\text {art }}=43 \mathrm{~min}$. These indicators are fully meet the requirements for the reliability of similar objects $T_{\text {perm. }} \geq 1000$ hrs. and $T_{\text {art.perm. }} \leq 60 \mathrm{~min}$., with $A^{\prime}=0,9993\left(U^{\prime}=0,0007\right)$.

Results of calculations for the same output data applying the mathematical model of reliability of Table 1, accounting the properties of the radio station in two modes, depending on the work time to "reception" or "transmission" is shown in Fig. 3-6. 


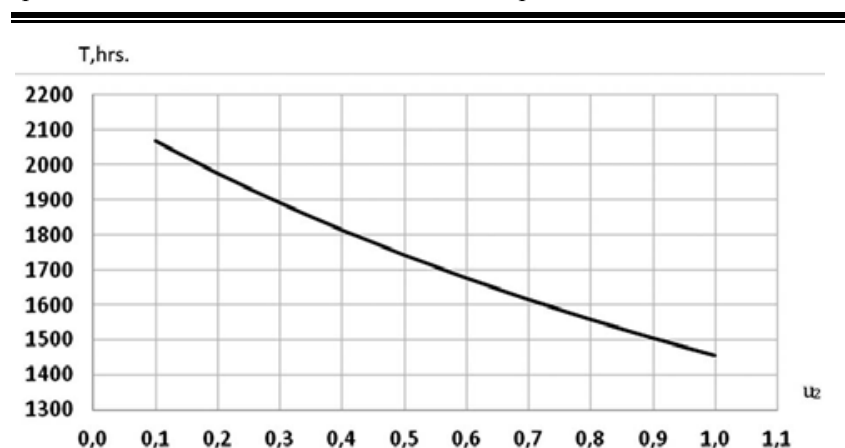

Figure 3 - Dependance of the radio station operation time for failure to from the relative time of work in the "reception" mode",

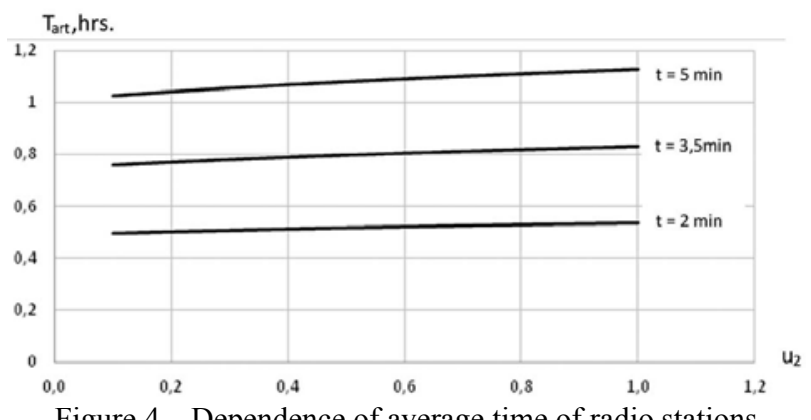

Figure 4 - Dependence of average time of radio stations recovery from the relative time of operation in the mode of "reception"

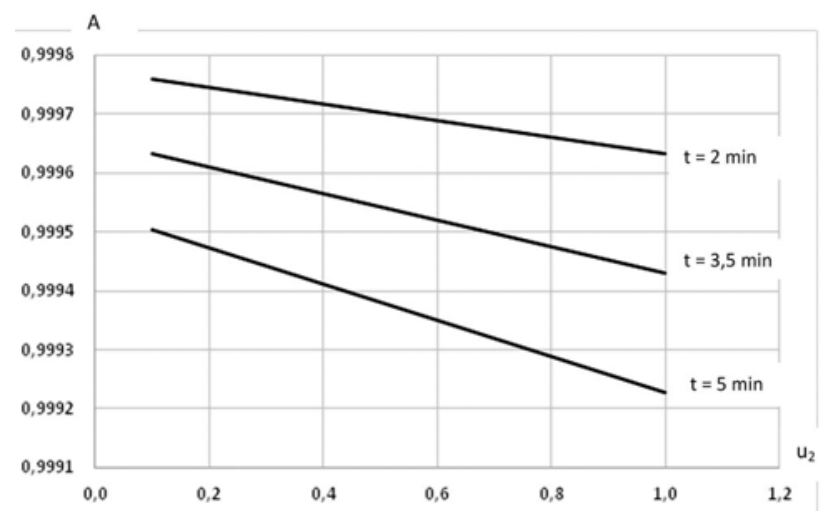

Figure 5 - Dependence of the readiness coefficient of the radio station from the relative time of operation in the "reception" mode

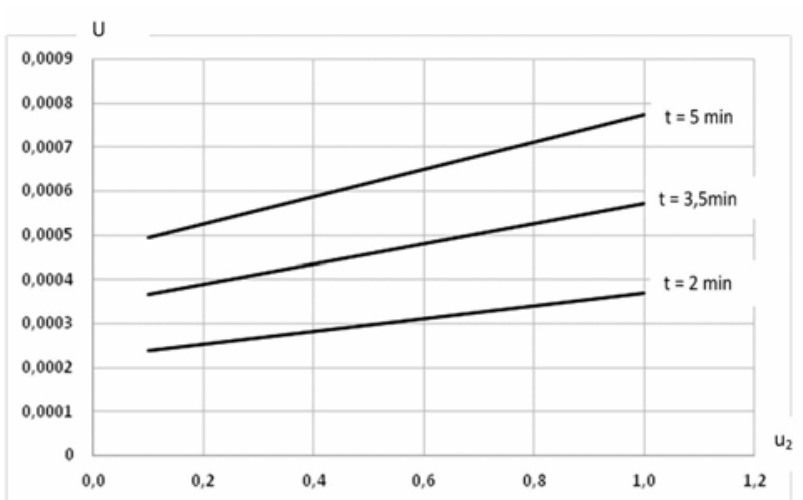

Figure 6-Dependence of the unreadiness coefficient of radio station from the relative time of operation in the "reception" mode

\section{RESULTS}

The analysis of the received dependencies shows that with an increase in the relative operation time of the radio station in the "receive" mode:

- the MTBF is reduced, since most radio station elements are used in this mode (Fig. 3);

- the average recovery time also does not significantly increase as the value of the probability of failure in the receiving part of the radio increases, and this pattern is maintained at any time during the verification of $t$ (Fig. 4);

- as a result of a decrease in the value of the operations time on failure of $T$ and an increase in the average recovery time $T_{\text {art }}$, the complex reliability indicator is also reduced - the readiness coefficient $A$ (Fig. 5) and, accordingly, the value of the unreadiness U-coefficient (Fig. 6) increases;

- the indicated tendencies are maintained at any values of the average check time $t$, moreover, its reduction leads to an increase in the readiness factor (A) by increasing the skills of the operators and improving the diagnostic support (the selection of checks with smaller losses).

Comparison of the results with the prototype (calculation of similar indicators without accounting multi-mode radio station) shows that when radio station operates $90 \%$ of the time in the mode of "reception" $\left(u_{2}=0.9\right)$, which often takes place in practice, we have a specification of the operating time for a failure on $33 \%$ ( $T=1507 \mathrm{hrs}$.), the average recovery time on $14 \%$ $\left(T_{\text {art }}=50 \mathrm{~min}\right.$. ) and the reduction in the unreadiness coefficient by $28 \%$ ( $U=0.000548)$. Thus, it was possible to use less expensive elements to provide the necessary requirements for the reliability of the radio station during its design and production.

\section{DISCUSSION}

The analysis of the results shows that the proposed mathematical model of evaluation of reliability indicators values of REDs with variable structure (Table 1) allows to get real values of working time for failure, average recovery time and complex indicators of reliability coefficients of readiness and unavailability of multiple mode objects depending on real-time operation of subsets of elements in each mode. The adequacy of the model is confirmed by the transformation of the obtained mathematical relations to the known assumptions about the required work of elements subsets, the metrological reliability of measuring equipment, and the independence of the failure in the elements subset power.

The example of use of the received results for the evaluation of radio station reliability is given, the functional dependences of values of reliability indicators on the relative operating time in the "receive" mode are provided. It is established that at $90 \%$ of work in this mode there is a refinement in working time for failure by $33 \%$ and average recovery time by $14 \%$ in comparison 
with the existing models. Without taking into account the multi-mode property of the radio station, the operating time for failure meets the requirements, but only if it is considered 1.5 times more. That is, to ensure the requirements for the reliability of the radio station a different element base can be used, which reduces the cost of the product.

The following should be stated as a restriction on the use of the proposed model:

- in different product operational modes not all subsets of elements work simultaneously (in this case existing models should be used);

- relative time of using a subset of elements in separate modes is known in advance.

Application of the results obtained in the framework of the research project devoted to the development of the tropospheric communication station with a complex signal allowed one to improve the specification of the operating time for failure by $29 \%$, the average recovery time up to $12 \%$ and to increase the readiness during the trial operation by $26 \%$.

Research findings should be used to evaluate the reliability of objects with a limited power supply (for its ecology, a subset of elements that are not required to perform tasks are disabled), which include spacecraft, automatic planetary exploration stations, deep-sea research vehicles, and others.

\section{CONCLUSIONS}

The traditional assessment of the operations time for failure of the technical objects without accounting of their multi-mode operation reduces the value of this reliability index. Consequently, if it meets the requirements, then the actual value of the operations time for failure will be greater, which affects the cost of the product. Considering the properties of the multi-mode radio electronic devices, it is possible to specify the value of the operations time for failure and the average recovery time: the existing models underestimate the value of operating time for failure and the average recovery time.

Using the suggested model of the quantitative evaluation of reliability indicators of radio-electronic devices with variable structure allows reducing the cost of products, by providing the required values of operations time for failure and average recovery time by reducing the requirements to the reliability of the element base.

The closest to the subject under consideration is the method of proportional distribution of reliability but it cannot be used to create new promising samples based on a new element base because the data on the operation of analogs are not available.

The scientific novelty of the research results consists in the development of a mathematical model for assessing the reliability indicators of objects with a variable structure. The model takes into account the operating time of subsets of the elements of the object in possible modes, and also account for the influence of the quality of metrological and diagnostic support on the maintainability of the object as a whole.

(C) Ryzhov Ye. V., Sakovich L. N., Puchkov O. O. Nebesna Ya. E., 2020 DOI 10.15588/1607-3274-2020-3-3
The practical importance of the obtained results consists in the possibility of providing the required level of reliability of objects with a variable structure at the minimum necessary values of the failure rate of the element base, which will lead to a decrease in the cost of products for the required values of quality indicators.

The obtained results are appropriate to use during the design of advanced communications devices in assessment of their operations time for failure, which provide a possibility to reduce the cost of products due to the rational choice of elements of multi-mode RED objects.

Further research should be directed to the development of a method for evaluation of reliability indicators of objects with a variable structure using the resulting model, as well as to assess the reliability of systems in general with their usage [18-20].

\section{ACKNOWLEDGEMENTS}

This work was supported by the Hetman Petro Sahaidachnyi National Army Academy (Lviv, Ukraine).

\section{REFERENCES}

1. Handbook of 217 PlusTM. Reliability Prediction Models. - USA: RIAC, 2006, 186 p. URL: https://books.google.com.ua/books?id=33rW29AytewC $\& p g=$ PA1\&hl $=$ ru\&source $=$ gbs_toc_r\&cad $=4 \# \mathrm{v}=$ onepage $\& \mathrm{q} \& \mathrm{f}=$ false

2. Yamada S., Tamura Y. Software Reliability / S. Yamada, // In: OSS Reliability Measurement and Assessment. Springer Series in Reliability Engineering. - Cham: Springer. - 2016. - P. 1-13. DOI: https://doi.org/10.1007/978-3-319-31818-9_1.

3. Manzini R., Regattieri A., Pham H., Ferrari E. Reliability Evaluation and Reliability Prediction Models, Maintenance for Industrial Systems. London, Springer Series in Reliability Engineering, 2010, 187 p. DOI: https://doi.org/10.1007/978-1-84882-575-8 6 .

4. Hao Sun, Cai Xiaoxia, Chen Hong Study on Parameter Evaluation System of Communication Network, Procedia Computer Science, 2017, Vol. 107, pp. 584589.

DOI: https://doi.org/10.1016/j.procs.2017.03.139.

5. Rongxing Duan, Fan Jinghui Reliability Evaluation of Data Communication System Based on Dynamic Fault Tree under Epistemic Uncertainty, Mathematical Problems in Engineering, Vol. 2014, Article ID 674804, 9

DOI: https://doi.org/10.1155/2014/674804

6. Qiao Ma., Guibo Yu, Lijun Cao, Jinhui Zhao, Bing Feng Decision-making model for ranking battlefield damaged equipment repairs based on multi-criteria, 2013 International Conference on Quality, Reliability, Risk, Maintenance, and Safety Engineering (QR2MSE), 15-18 July 2013, Emeishan, Sichuan. China, Proc. IEEE, 2013, Vol. II, pp. 1942-1944. DOI: http://dx.doi.org/10.1109/QR2MSE.2013.6625959.

7. Khandpur R. S. Troubleshooting Electronic Equipment: Includes Repair And Maintenance, Second Edition. New York, McGraw Hill Education (India) Private Limited, 2003,

$$
422 \mathrm{p} \text {. }
$$

URL: 
https://www.accessengineeringlibrary.com/content/book/ 9780070483576.

8. Jonathan Swingler. Reliability Characterisation of Electrical and Electronic Systems. Woodhead Publishing, 2015, 274 p. DOI: https://doi.org/10.1016/C2013-016487-2.

9. Military handbook: reliability prediction of electronic equipment, MIL-HDBK-217F, (02-Dec-1991), 150 p.

10. Kharchenko V.A. Problems of reliability of electronic components, Modern Electronic Materials, 2015, Vol. 1, Issue $\quad 3, \quad P$. 88-92. DOI: http://dx.doi.org/10.1016/j.moem.2016.03.002.

11. Villanueva Ignacio, L.ázaro Isidro, Anzurez Juan Reliability analysis of LED-based electronic devices, Procedia Engineering, 2012, Vol. 35. pp. 260-269. DOI: http://dx.doi.org/10.1016/j.proeng.2012.04.189.

12. Catelani M., Ciani L. Experimental tests and reliability assessment of electronic ballast system, Microelectronics Reliability, 2012, Vol. 52, Issues 9-10, pp. 1833-1836. DOI: http://dx.doi.org/10.1016/j.microrel.2012.06.077.

13. Yi Wan, Hailong Huang, Diganta Das, Michael Pecht Thermal reliability prediction and analysis for highdensity electronic systems based on the Markov process, Microelectronics Reliability, 2016, Vol. 56, pp. 182-188. DOI: https://doi.org/10.1016/j.microrel.2015.10.006.

14. Romanenko V. P., Sakovych L. N., Ryzhov Y. V., Gnatyuk S. E. , Rozum I. Y. Methodology of justification the type and evaluation of quality group search of defects in the repair radio-electronic means, Radio Electronics, Computer Science, Control, 2019, No. 1. pp. 18-28. DOI: https://doi.org/10.15588/1607-3274-2019-1-2.

15. Robert B. Ash. Basic Probability Theory. New York: Dover Publications, 2008, 352 p. URL: https://faculty.math.illinois.edu/ r-ash/BPT/BPT.pdf.

16. Kononov V., Ryzhov Ye., Sakovych L. Dependence of parameters of repair of military communication means on the quality of metrological support, Advanced Information Systems, 2018, Vol. 2, No. 1, pp. 91-95. DOI: https://doi.org/10.20998/2522-9052.2018.1.17.

17. RF-7850M-HH multiband handheld radio. Operation manual. Rochester, Publication number: 10515-04614200, 2014, 237 p.

18. Ryzhov Ye., Sakovych L., Vankevych P., Yakovlev M., Nastishin Yu. Optimization of requirements for measuring instruments at metrological service of communication tools, Measurement 123, 2018, pp. 1925 .

DOI: https://doi.org/10.1016/j.measurement.2018.03.055.

19. Herasimov S., Pavlii V., Tymoshchuk O., Yakovlev M. Yu., Khaustov D. Ye., Ryzhov Ye., Sakovych L., Nastishin Yu. A. Testing Signals for Electronics: Criteria for Synthesis, Journal of Electronic Testing, 2019, Vol. 35, No. 3, pp. 349-357. DOI: https://doi.org/10.1007/s10836-019-05798-9.

Received 15.10.2019. Accepted 22.06.2020.

УДК 621.396 .6

\section{ОЦІНКА НАДІЙНОСТІ РАДІОЕЛЕКТРОННИХ ЗАСОБІВ ЗІ ЗМІННОЮ СТРУКТУРОЮ}

Рижов С. В. - канд. техн. наук, начальник науково-дослідної лабораторії (інформаційних та геоінформаційних систем) Наукового центру Сухопутних військ Національної академії сухопутних військ імені гетьмана Петра Сагайдачного, м. Львів, Україна.

Сакович Л. М. - канд. техн. наук, доцент, доцент спеціальної кафедри № 4 Інституту спеціального зв’язку та захисту інформації КПІ імені Ігоря Сікорського, м. Київ, Україна.

Пучков О. О. - канд. філософс. наук, професор, начальник Інституту спеціального зв’язку та захисту інформації КП імені Ігоря Сікорського, м. Київ, Україна.

Небесна Я. Е. - начальник сектору планування та контролю навчального процесу навчального відділу Інституту спеціального зв’язку та захисту інформації КПІ імені Ігоря Сікорського, м. Київ, Україна.

\section{АНОТАЦІЯ}

Актуальність. Радіоелектронні засоби різноманітного призначення безперервно розвиваються i удосконалюються в напрямку покращення показників якості відповідно до вимог споживачів щодо їх використання в багатьох режимах роботи, в кожному з яких працюють окремі підмножини елементів. Цю обставину не враховують під час оцінки показників надійності, що веде до зниження їх значення, i, як наслідок, до підвищення вартості виробів.

Мета. Метою статті є підвищення точності кількісної оцінки значень показників надійності радіоелектронних засобів зі змінною структурою за рахунок використання нової моделі, яка враховує час роботи окремих підмножин елементів об'єкта в можливих режимах його роботи.

Метод. В роботі виконано аналіз структур радіоелектронних засобів та їх вплив на надійність з застосуванням методів теорії множин, теорії ймовірностей, теорії дискретного пошуку та метрології. Це дозволяє об'єктивно, в залежності від умов експлуатації виробу, кількісно оцінити значення показників надійності: наробіток на відмову, середній час відновлення і коефіцієнт готовності.

Результати. Отримано удосконалену модель надійності багато режимних об'єктів зі змінною структурою, яка враховує особливості конструктивно-схемної побудови виробу, особливості його використання за призначенням (час роботи в окремих режимах), вплив якості метрологічного забезпечення на середній час відновлення. Це дозволяє збільшити оцінку реального значення комплексного показника надійності - коефіцієнта готовності, i, як наслідок, зменшити значення коефіцієнту не готовності. 
Висновки. Використання запропонованої моделі кількісної оцінки значень показників надійності радіоелектронних засобів зі змінною структурою дозволяє знизити вартість виробів при забезпеченні необхідних значень наробітку на відмову і середнього часу відновлення за рахунок зниження вимог до надійності елементів бази. Отримані результати доцільно використовувати під час проектування перспективних радіоелектронних засобів для обгрунтування вибору елементої бази мінімальної вартості при забезпеченні заданих вимог до надійності виробу в цілому.

КЛЮЧОВІ СЛОВА: радіоелектронні засоби зі змінною структурою, оцінка показників надійності, наробіток на відмову, середній час відновлення.

УДК 621.396 .6

\section{ОЦЕНКА НАДЕЖНОСТИ РАДИОЭЛЕКТРОННЫХ СРЕДСТВ С ПЕРЕМЕННОЙ СТРУКТУРОЙ}

Рыжов Е. В. - канд. техн. наук, начальник научно-исследовательской лаборатории (информационных и геоинформационных систем) Научного центра Сухопутных войск Национальной академии сухопутных войск имени гетмана Петра Сагайдачного, г. Львов, Украина.

Сакович Л. М. - канд. техн. наук, доцент, доцент специальной кафедры № 4 Института специальной связи и защиты информации КПИ имени Игоря Сикорского, г. Киев, Украина.

Пучков А. А. - канд. философс. наук, профессор, начальник Института специальной связи и защиты информации КПИ имени Игоря Сикорского, г. Киев, Украина.

Небесная Я. Э. - начальник сектора планирования и контроля учебного процесса учебного отдела Института специальной связи и защиты информации КПИ имени Игоря Сикорского, г. Киев, Украина.

\section{АННОТАЦИЯ}

Актуальность. Радиоэлектронные средства различного назначения непрерывно развиваются и совершенствуются в направлении улучшения показателей качества в соответствии с требованиями потребителей по их использованию во многих режимах работы, в каждом из которых работают отдельные подмножества элементов. Это обстоятельство не учитывают при оценке показателей надежности, что ведет к снижению их значения, и, как следствие, к повышению стоимости изделий.

Цель. Целью статьи является повышение точности количественной оценки значений показателей надежности радиоэлектронных средств с переменной структурой за счет использования новой модели, которая учитывает время работы отдельных подмножеств элементов объекта в возможных режимах его работы.

Метод. В работе выполнен анализ структур радиоэлектронных средств и их влияние на надежность с применением методов теории множеств, теории вероятностей, теории дискретного поиска и метрологии. Это позволяет объективно в зависимости от условий эксплуатации изделия, количественно оценить значения показателей надежности: наработка на отказ, среднее время восстановления и коэффициент готовности.

Результаты. Получено усовершенствованную модель надежности многорежимных объектов с переменной структурой, которая учитывает особенности конструктивно-схемного построения изделия, особенности его использования по назначению (время работы в отдельных режимах), влияние качества метрологического обеспечения на среднее время восстановления. Это позволяет увеличить оценку реального значения комплексного показателя надежности - коэффициента готовности, и, как следствие, уменьшить значение коэффициента неготовности.

Выводы. Использование предложенной модели количественной оценки значений показателей надежности радиоэлектронных средств с переменной структурой позволяет снизить стоимость изделий при обеспечении требуемых значений наработки на отказ и среднего времени восстановления за счет снижения требований к надежности элементной базы. Полученные результаты целесообразно использовать при проектировании перспективных радиоэлектронных средств для обоснования выбора элементной базы минимальной стоимости при обеспечении заданных требований к надежности изделия в целом.

КЛЮЧЕВЫЕ СЛОВА: радиоэлектронные средства с переменной структурой, оценка показателей надежности, наработка на отказ, среднее время восстановления.

\section{ЛІТЕРАТУРА / ЛИТЕРАТУРА}

1. Handbook of 217 PlusTM. Reliability Prediction Models. - USA: RIAC, 2006. - 186 p. URL: https://books.google.com.ua/books?id=33rW29AytewC $\& p g=P A 1 \& \mathrm{hl}=\mathrm{ru} \&$ source $=\mathrm{gbs} \_$toc_r\&cad $=4 \# \mathrm{v}=$ onepage $\& \mathrm{q} \& \mathrm{f}=$ false

2. Yamada S. Software Reliability / S. Yamada, Y. Tamura // In: OSS Reliability Measurement and Assessment. Springer Series in Reliability Engineering. - Cham : Springer. - 2016. - P. 1-13. DOI: https://doi.org/10.1007/978-3-319-31818-9_1.

(C) Ryzhov Ye. V., Sakovich L. N., Puchkov O. O. Nebesna Ya. E., 2020 DOI 10.15588/1607-3274-2020-3-3
3. Reliability Evaluation and Reliability Prediction Models / [R. Manzini, A. Regattieri, H. Pham, E. Ferrari] // Maintenance for Industrial Systems. - London : Springer Series in Reliability Engineering, 2010. - 187 p. DOI: https://doi.org/10.1007/978-1-84882-575-8_6.

4. Hao Sun. Study on Parameter Evaluation System of Communication Network / Hao Sun, Xiaoxia Cai, Hong Chen // Procedia Computer Science. - 2017. Vol. 107 $\quad-\quad$ P. 584-589. https://doi.org/10.1016/j.procs.2017.03.139.

5. Rongxing Duan. Reliability Evaluation of Data Communication System Based on Dynamic Fault Tree 
under Epistemic Uncertainty / Rongxing Duan, Jinghui Fan // Mathematical Problems in Engineering. Vol. 2014, Article ID 674804. -9 p. DOI: https://doi.org/10.1155/2014/674804.

6. Decision-making model for ranking battlefield damaged equipment repairs based on multi-criteria / [Qiao Ma, Guibo Yu, Lijun Cao et al] // 2013 International Conference on Quality, Reliability, Risk, Maintenance, and Safety Engineering (QR2MSE), 15-18 July 2013, Emeishan, Sichuan, - China : Proc. IEEE, 2013. $\begin{array}{llll}\text { Vol. II. } & - & \text { P. 1942-1944. }\end{array}$ http://dx.doi.org/10.1109/QR2MSE.2013.6625959.

7. Khandpur R. S. Troubleshooting Electronic Equipment: Includes Repair And Maintenance, Second Edition / R. S. Khandpur. - New York : McGraw Hill Education (India) Private Limited, 2003. - 422 p. URL: https://www.accessengineeringlibrary.com/content/book/ 9780070483576.

8. Jonathan Swingler. Reliability Characterisation of Electrical and Electronic Systems / Jonathan Swingler. Woodhead Publishing, 2015. - 274 p. DOI: https://doi.org/10.1016/C2013-0-16487-2.

9. Military handbook: reliability prediction of electronic equipment, MIL-HDBK-217F, (02-Dec-1991). - 150 p.

10. Kharchenko V. A. Problems of reliability of electronic components / V. A. Kharchenko // Modern Electronic Materials. - 2015. - Vol. 1, Issue 3. - P. 88-92. DOI: http://dx.doi.org/10.1016/j.moem.2016.03.002.

11. Villanueva Ignacio. Reliability analysis of LED-based electronic devices / Villanueva Ignacio, L.ázaro Isidro, Anzurez Juan // Procedia Engineering. - 2012. Vol. 35. - $\quad$ P. $260-269 . \quad$ DOI: http://dx.doi.org/10.1016/j.proeng.2012.04.189.

12. Catelani M. Experimental tests and reliability assessment of electronic ballast system / M. Catelani, L. Ciani // Microelectronics Reliability. - 2012. - Vol. 52, Issues 9-
10. -
P.
$1833-1836$.
DOI:

http://dx.doi.org/10.1016/j.microrel.2012.06.077.

13. Yi Wan Thermal reliability prediction and analysis for high-density electronic systems based on the Markov process / Yi Wan, Hailong Huang, Diganta Das, Michael Pecht // Microelectronics Reliability. - 2016. Vol. $56 . \quad-\quad$ P. $182-188$. DOI: https://doi.org/10.1016/j.microrel.2015.10.006.

14. Romanenko V. P. Methodology of justification the type and evaluation of quality group search of defects in the repair radio-electronic means / [V. P. Romanenko, L. N. Sakovych, Y. V. Ryzhov et al.] // Radio Electronics, Computer Science, Control. - 2019. - No. 1. - P. 18-28. DOI: https://doi.org/10.15588/1607-3274-2019-1-2.

15. Robert B. Ash. Basic Probability Theory / Robert B. Ash. - New York : Dover Publications. - 2008. - 352 p. URL: https://faculty.math.illinois.edu/ r-ash/BPT/BPT.pdf.

16. Kononov V. Dependence of parameters of repair of military communication means on the quality of metrological support / V. Kononov, Ye. Ryzhov, L. Sakovych // Advanced Information Systems. - 2018. Vol. 2, No. 1. - P. 91-95. DOI: https://doi.org/10.20998/2522-9052.2018.1.17.

17. RF-7850M-HH multiband handheld radio. Operation manual. - Rochester : Publication number: 10515-04614200. - 2014. - 237 p.

18. Ryzhov Ye. Optimization of requirements for measuring instruments at metrological service of communication tools / [Ye. Ryzhov, L. Sakovych, P. Vankevych et al.] // Measurement 123. - 2018. - P. 19-25. DOI: https://doi.org/10.1016/j.measurement.2018.03.055.

19. Testing Signals for Electronics: Criteria for Synthesis / [S. Herasimov, V. Pavlii, O. Tymoshchuk et al.] // Journal of Electronic Testing. - 2019. - Vol. 35, No. 3. P. 349-357. DOI: https://doi.org/10.1007/s10836-01905798-9. 